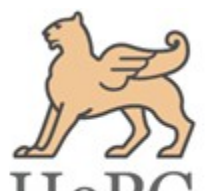
HePG

ISSN: 2348-1900

Plant Science Today

http://horizonepublishing.com/journals/index.php/PST

\title{
Anisochilus carnosus (L. f.) Wall. ex Benth. (Lamiaceae) - a new generic record for Pakistan
}

\author{
Ashfaq Ali, ${ }^{1}$ Mahrine Rashid, ${ }^{2}$ Amir Sultan, ${ }^{2}$ and Muhammad $\operatorname{Irfan}^{1}$ \\ ${ }^{1}$ Department of Botany, Hazara University, Mansehra, Khyber Pakhtunkhwa, Pakistan \\ ${ }^{2}$ National Herbarium (Stewart Collection), National Agricultural Research Centre, Park Road, Islamabad, Pakistan
}

Article history

Received: 21 June 2017

Accepted: 27 June 2017

Published: 14 July 2017

(C) Ali et al. (2017)

Editor

K K Sabu

Publisher

Horizon e-Publishing Group

Correspondence

Amir Sultan

$\triangle$ amirsultan_2000@yahoo.com

\begin{abstract}
During an exploration of Gadoon area in district Swabi, Khyber Pakhtunkhwa a specimen of Anisochilus carnosus (L. f.) Wall. ex Benth. was collected which represents a new plant record for Pakistan. Its description and illustrations are provided for easy identification.
\end{abstract}

Keywords

Lamiaceae; Anisochilus carnosus; Swabi; Khyber Pakhtunkhwa; Pakistan.

Ali, A., M. Rashid, A. Sultan and M. Irfan. 2017. Anisochilus carnosus (L. f.) Wall. ex Benth. (Lamiaceae) - a new generic record for Pakistan. Plant Science Today 4(3): 102-105. http://dx.doi.org/10.14719/pst.2017.4.3.316

\section{Introduction}

The genus Anisochilus comprises 16 species and is mainly distributed in India, Sri Lanka, Himalaya, Burma, south China, Thailand and Indo-China (Suddee and Paton, 2009). Anisochilus carnosus is known from Southern China, Thailand, Burma, Nepal, India, and Sri Lanka (Suddee and Paton, 2009).

A specimen was collected by the first author (Ashfaq Ali) on 20 September, 2013 from Gadoon area of district Swabi, in Khyber Pakhtunkhwa. The plant appeared to be a novelty for flora of Pakistan. Some seeds were carefully isolated from the only herbarium specimen available and were grown in the live repository at National Herbarium for further examination. A plant grown from the seed was later sent to Dr. Alan Paton (Kew) who confirmed its identity as Anisochilus carnosus.

The plant has neither documented in Stewart's annotated catalogue (1972) nor in the account of the family Labiatae (Lamiaceae) in the flora of Pakistan (Hedge, 1990) and thus represents a new record for Pakistan. Its occurrence represents an extension in known range of this species as the closest records of this species are from Himachal Pradesh (India) (Suddee and Paton, 2009). 


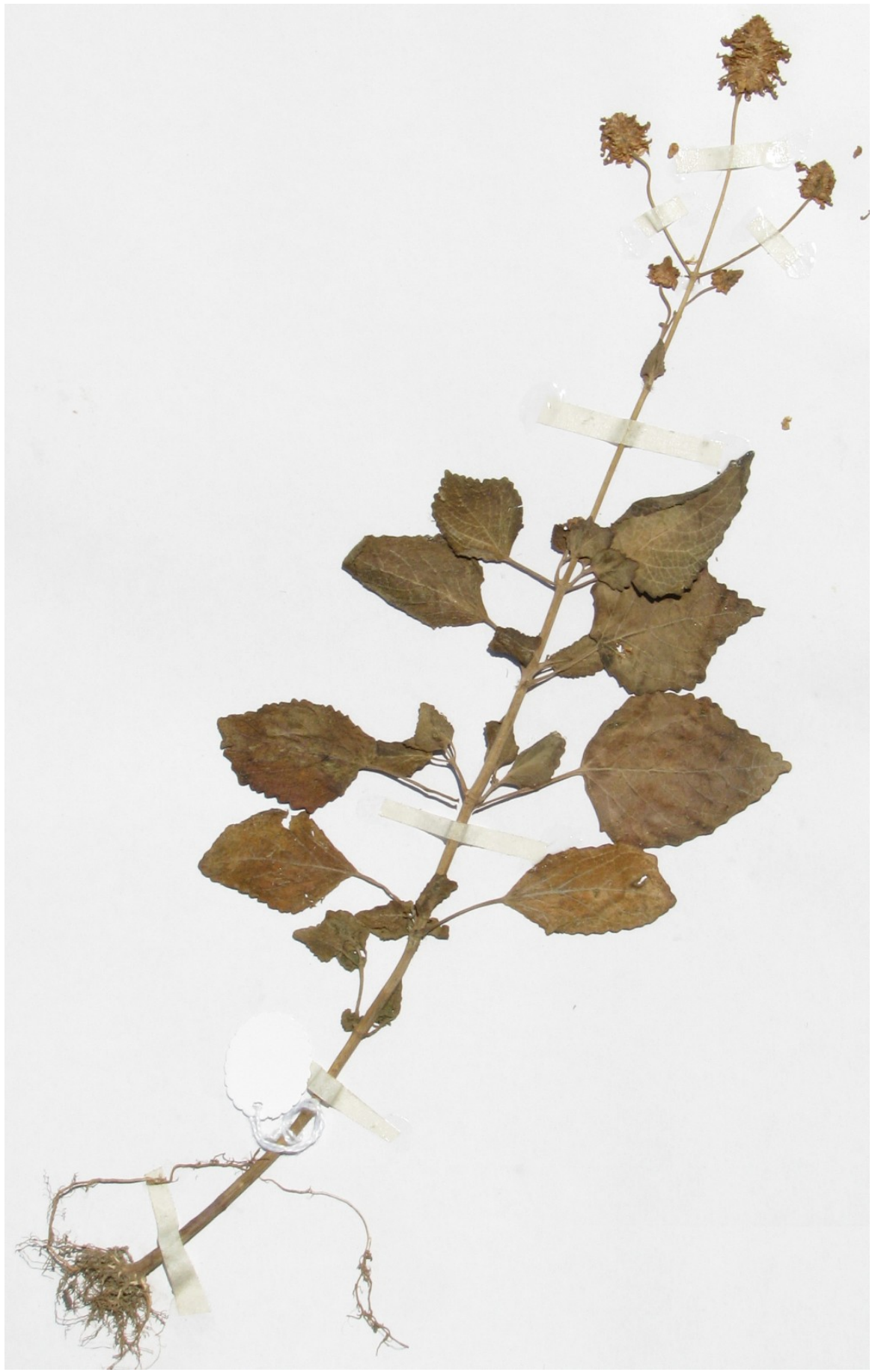

Fig. 1. Herbarium specimen of Anisochilus carnosus (Ashfaq Ali 56).

Anisochilus carnosus (L. f.) Wall. ex Benth. in N.Wallich, Pl. Asiat. Rar. 2 (5): 18. 1830. Lavandula carnosa, L.f : Suppl. Pl. 273. 1782 [1781 publ. Apr 1782]. Anisochilus crassus Benth., Prodr.12: 81.1848. Anisochilus decussatus Dalzell \& Gibson.,Bombay Fl. 206.1861. Anisochilus rupestris Wight ex Hook. f., Fl. Brit. India 4: 627.1833.

\section{Taxonomic description}

Annual herbs, up to $37 \mathrm{~cm}$ tall; stem erect, quadrangular, internodes 2.5-6 cm long, densely covered with appressed hairs. Leaves opposite, petiolate, petiole $0.5-3 \mathrm{~cm}$ long; lamina broadly ovate to rhomboid or oblongovate, $2.8-5.4 \times 2.4-4.2 \mathrm{~cm}$, obtuse to shortly acuminate, margins crenate, subcordate to round or subtruncate puberulent, densely brown spotted on both surfaces, secondary veins up to 16 pairs, alternate, opposite or subopposite. Inflorescence subglobose spike arranged in dichasial cymes, upper peduncle up to $5.7 \mathrm{~cm}$ long, lateral ones up to $4 \mathrm{~cm}, 2$ basal bracts present, pubescent, 1-2 mm long. Flowers sessile or short pedicellate $0.5-1.0 \mathrm{~mm}$ long; calyx 4-4.5 mm long, densely pubescent 


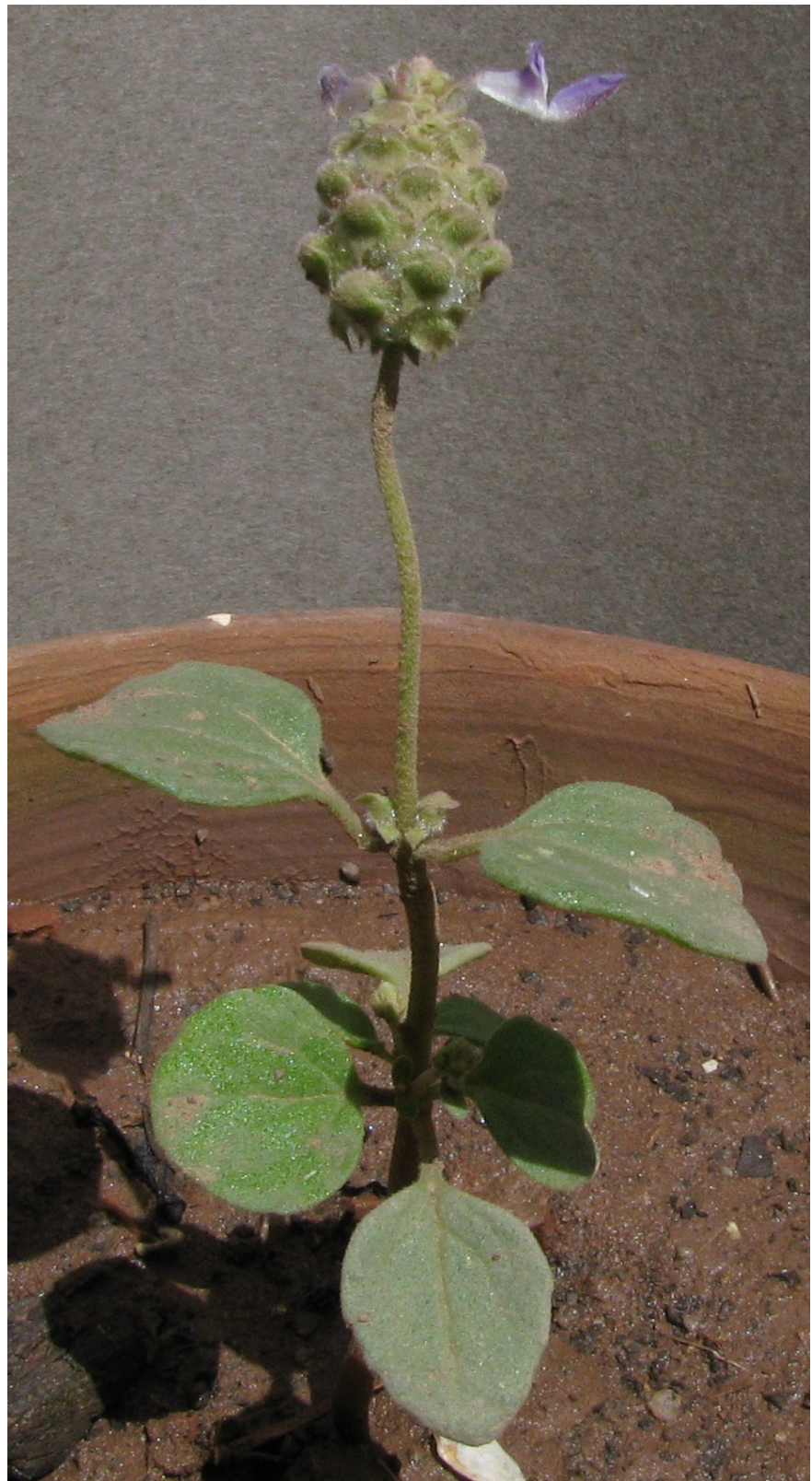

Fig. 2. Anisochilus carnosus plant grown from seed isolated from the herbarium specimen

tube with 1.5-2.0 $\mathrm{mm}$ dilated base and an upper lip of 2.0 - $3.0 \mathrm{~mm}$ long, reflexed, acute, tip of upper lip suffused with red/pink, fruiting calyx dilated, 7- $8 \mathrm{~mm}$ long; corolla purple, 6-9 $\mathrm{mm}$ long, tube slender, exerted, recurved, visible part $4 \mathrm{~mm}$ long, densely covered with soft hairs and red glands, upper lip up to $3 \mathrm{~mm}$ long, shorter than lower lip, 4 lobed, lateral lobes transparent to white, smaller, middle lobes purplish, lower lip up to 4-5 $\mathrm{mm}$ long, concave/boat shaped; stamens 4, anthers dark purple, dorsifixed. Nutlets 4 , broadly ovate, black, $1 \times 0.8 \mathrm{~mm}$, inconspicuously emarginated at apex.

Specimen Gadoon, examined: Pakistan: Swabi District,
Pakhtunkhwa, 20 September 2013, Ashfaq Ali, (RAW).

The plant is used extensively in folk medicine for the treatment of gastric ulcer and skin diseases (Bhagat et al., 2014) and is cultivated in China for its medicinal value ( $\mathrm{Li}$ and Hedge, 1994). The present record represents the westernmost distribution recorded so far. The plant may have a wider distribution and may potentially be present in suitable habitats in Jammu and Kashmir.

\section{Acknowledgements}

We are thankful to Dr. Alan Paton, Royal Botanic Gardens, Kew for confirming the identity of plant and to Mr. Sayed Afzal Shah for reviewing the description. 


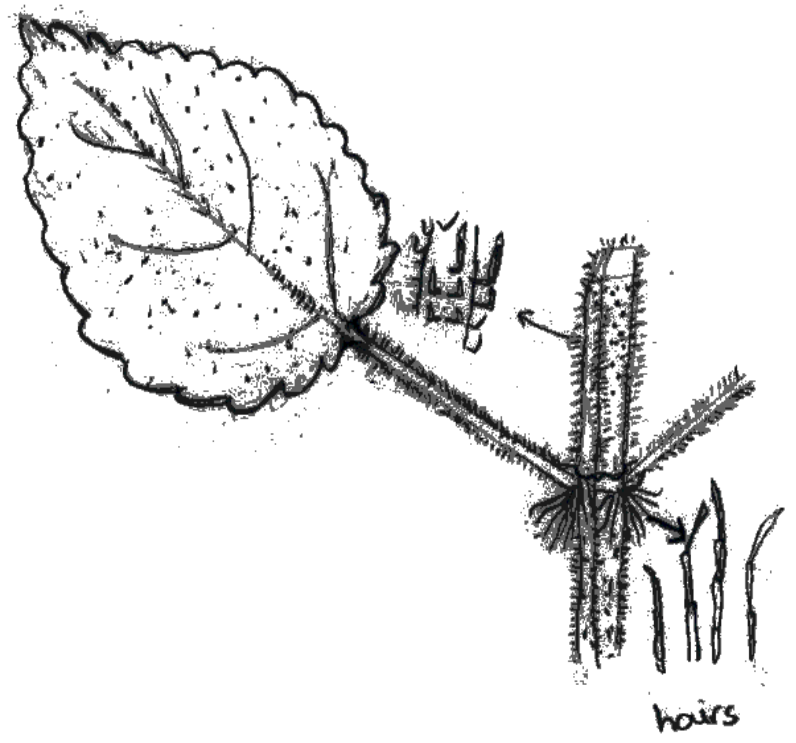

a

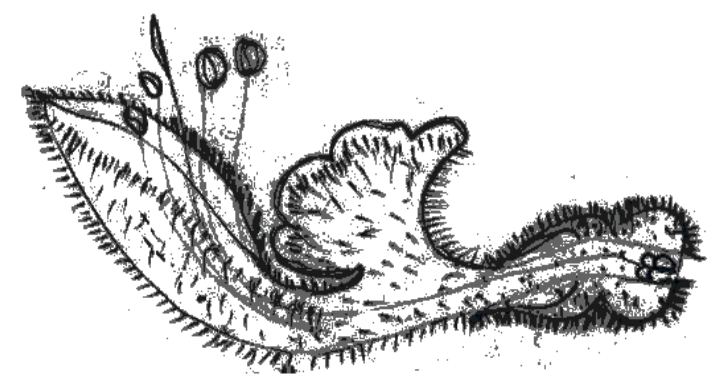

$\mathrm{b}$

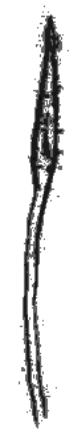

c

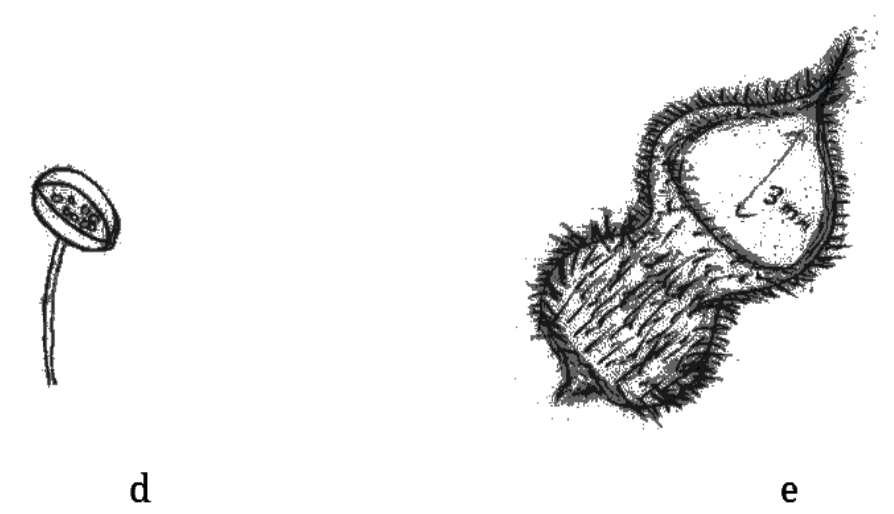

Fig. 3. a. Portion of stem showing leaf, nodal and intermodal hairs, b. calyx and corolla split open showing pistil and stamens, c. stigma and style, d. stamen, e. fruiting calyx

\section{References}

Bhagat, J., Lobo, R., Kumar, N., Mathew, J. E. and Pai, A. 2014. Cytotoxic potential of Anisochilus carnosus (L.f.) wall and estimation of luteolin content by HPLC. BMC Complementary and Alternative Medicine 14: 421. https://doi.org/10.1186/1472-6882-14-421

Hedge, I. C. 1990. In Ali S. I. and Nasir Y. J. (Eds.) Flora of Pakistan (Labiatae). No. 192.310 p.

Li, X. and Hedge, I. C. 1994. Flora of China (Lamiaceae) 17: 50-299.
Stewart, R. R. 1972. An annotated catalogue of the vascular plants of West Pakistan and Kashmir (Flora of Pakistan). Fakhri Printing Press, Karachi.

Suddee, S. and Paton, A. 2009. A revision of Anisochilus Wall. ex Benth. (Lamiaceae). Kew Bulletin 64: 235-257. https://doi.org/10.1007/s12225-009-9115-5 